\title{
Wits Appraisal of a Qatari Male Population: A Comparative Study. Part II
}

\author{
Hayder A Hashim, Najat Al-Sayed, and Ayah AL-Qaisi
}

\section{ABSTRACT}

\begin{abstract}
Introduction: Cephalometric analysis aims to determine skeletal and dental relationships. The ANB angle, initially suggested by Rediel and applied by Steiner. is the most used angle in establishing the anteroposterior relationship of the mandible to the maxilla. However, limitations to the accuracy of the ANB angle for this purpose have been reported. To avoid these potential sources of inaccuracy a diagnostic tool was introduced by Jenkins and later modified by Jacobson and became known as the "Wits appraisal". Aims: The aim of this study was to establish the Wits appraisal value in a sample of Qatari males, a group which had not previously been studied in this context, and to compare the findings with those from racially and ethnically differing groups as reported in the literature.
\end{abstract}

Materials and Methods: The sample consisted of 28 lateral cephalometric radiographs of Qatari males with an age range of 15 to 32 years, presenting with a well-balanced facial appearance and an acceptable profile.

Results: The mean value of the Wits appraisal for Qatari males in the present study was $0.50 \pm 2.96$. This differed at a statistically significant level from the mean value in the Jacobson study with no gender significant difference noted. On the other hand, significant differences were found when compared with previous reports on different races.

Conclusion: The Wits appraisal value for the Qatari male population studied was $0.5 \pm 2.96$, a result which is significantly higher than that reported in Jacobson's study. This study revealed that the Wits appraisal is not ethnicity or gender-specific, and therefore cannot be used to differentiate between different ethnic groups. However, it can find application as an alternative to the ANB angle in the treatment of borderline cases. The application of cone beam computed tomography (CBCT) will enhance the diagnosis and treatment of cases by yielding three-dimensional views.

Keywords: Cephalometric; Orthodontic treatment; Wits appraisal. Males, Races.

\section{INTRODUCTION}

Cephalometric analysis aims to determine skeletal and dental relationships [1]-[10]. The ANB angle, initially suggested by Rediel [11] and applied by Steiner [12], is the most used angle in establishing the anteroposterior relationship of the mandible to the maxilla. However, limitations to the accuracy of the ANB angle for this purpose have been reported. Among these factors are age, the spatial position of the Nasion point, the upward or downward rotation of the jaw producing a variation in the orientation of the cranial base to the occlusal plane, and the degree of facial prognathism [13]-[18]. To avoid these potential sources of inaccuracy a diagnostic tool was introduced by Jenkins [19] and later modified by Jacobson, which became known as the "Wits appraisal" [9]. By drawing perpendicular lines from Point, A and Point B to the occlusal plane and measuring the horizontal linear distance between these two perpendicular lines Jacobson established the Wits appraisal as a reliable
Published Online: December 28, 2020

ISSN: $2593-8339$

DOI: $10.24018 /$ ejmed.2020.2.6.615

\section{Hayder Abdalla Hashim *}

BDS, MSc

Department of Dentistry, Oral Health Institute, Hamad Medical Corporation, Qatar.

(e-mail: hahashim78@yahoo.com)

Najat Al-Sayed

BDS, MDs, PhD

Department of Dentistry, Oral Health Institute, Hamad Medical Corporation, College of Dental Medicine, Qatar University, Qatar .

Ayah AL-Qaisi

BDS

Department of Dentistry, Oral Health Institute, Hamad Medical Corporation, Qatar.

*Corresponding Author indicator of the sagittal relationship between the maxilla and mandible [9]. The study, which was conducted on a sample of 21 adult subjects with optimal occlusions, revealed that point $\mathrm{BO}$ was approximately $1 \mathrm{~mm}$ ahead of point $\mathrm{AO}$, with a range of -2 to $4 \mathrm{~mm}$ and a mean of $-1.17 \pm 1.9 \mathrm{~mm}$.

The Wits appraisal value for racially differing populations has been the subject of several investigations. Robertson and Pearson studied a population from South Wales and found the Wits appraisal to be $-0.1 \pm 1.9 \mathrm{~mm}$ in males and $-0.3 \pm 1.7 \mathrm{~mm}$ in females [20]. A study on Southern Chinese yielded values in the $-4.88 \pm 3.61 \mathrm{~mm}$ range for males and $-4.47 \pm 4.19 \mathrm{~mm}$ for females [21]. In Nigerians it was found to be $-4.15 \pm 3.65$ $\mathrm{mm}$ and $-3.06 \pm 2.96 \mathrm{~mm}$ respectively [22]. Several studies have reported on Arab populations: Al- Barakati determined the Wits value in a group of dental students from the central region of Saudi Arabia to be $0.82 \pm 2.20$ [23]. Zawawi [24] studied a sample from the Western region of Saudi Arabia and found values for males to be $-0.73 \pm 2.48$ and for females to be $1.79 \pm 2.06$. Bishara et al [15] reported the Wits appraisal 
for an Egyptian sample to be $-0.10 \pm 2.20$. $\mathrm{mm}$.

The aim of this study was to establish the Wits appraisal value in a sample of Qatari males, a group which had not previously been studied in this context, and to compare the findings with those from racially and ethnically differing groups as reported in the literature.

\section{MATERIAL AND METHOD}

\section{A. Subjects}

The lateral cephalometric radiographs of twenty-eight Qatari male patients between the ages of 15 and 32 years (mean 20.69 \pm 4.9 years) were studied. All subjects were considered to have a well-balanced facial appearance and an acceptable profile. They also had dental Class I occlusions with normal overjet and overbite, minor or no crowding or spacing, and no history of orthodontic treatment. Ethical approval and consent forms were completed for each participant.

\section{B. Method}

A lateral skull radiograph of diagnostic quality was made (Planmeca-Finland, ProMax $(84 \mathrm{kV}-16 \mathrm{~mA})$ total filtration $2.5 \mathrm{~mm} \mathrm{AI})$. The radiograph was taken by an experienced technician at a distance of five feet from the patient who was instructed to look straight ahead at his own eyes in a wallmounted mirror. All radiographs were hand traced by the same operator. The Wits appraisal was measured by drawing straight perpendicular lines from Point A (Subnasale) and Point B (Supramentale) to the functional occlusal plane and measuring the horizontal distance from point $\mathrm{AO}$ to $\mathrm{BO}$. (Fig 1).

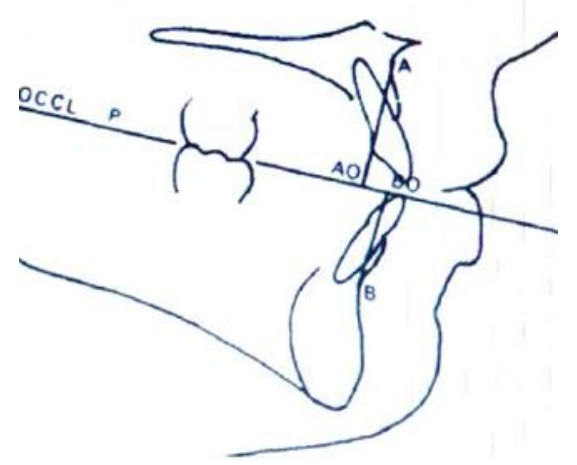

Fig. 1. Wits appraisal.

\section{Statistical Analysis}

Data analysis was carried out using Microsoft Excel software (Microsoft Corporation, California, USA). Descriptive statistics, including the mean and standard deviation (SD), were computed for each measurement. Student's t-test was used to establish the existence of any statistically significance differences between the Wits appraisal in this study and those from other published studies involving different racial and ethnic groups, including the Jacobson study. The level of significance was set at $\mathrm{p}<0.05$.

\section{RESULTS}

The error of method was assessed by double measurements taken a minimum of one week apart on five randomly selected cephalograms. The t-test result indicated an absence of any statistically significant difference between the two readings at the five percent level. $(\mathrm{P}>0.05)$. Table 1 . The mean value of the Wits appraisal for Qatari males in the present study was $0.5 \pm 3.8$.

\begin{tabular}{|c|c|c|c|c|c|}
\hline & No & Mean & SD & Minimum & Maximum \\
\hline $\begin{array}{l}\text { Qatari } \\
\text { males }\end{array}$ & 28 & 0.5 & 2.96 & -3 & 5 \\
\hline
\end{tabular}

Table 2 demonstrating the lack of any significant difference between Qatari males and females.

TABLE II: COMPARISON OF WITS APPRAISAL MEAN VALUES BETWEEN QATARI MALES AND FEMALES

\begin{tabular}{cccccc}
\hline \multicolumn{6}{c}{ QATARI MALES AND FEMALES } \\
\hline & No & Mean & SD & $\begin{array}{c}\text { P- } \\
\text { Value }\end{array}$ & Comment \\
\hline $\begin{array}{c}\text { Qatari males } \\
\text { Present study } \\
\begin{array}{c}\text { Qatari females } \\
\text { Hashim } \text { et al }(30)\end{array}\end{array}$ & 28 & 0.5 & 2.96 & & \\
\hline $\mathrm{P}<0.05 *, \mathrm{P}<0.01 * *, \mathrm{P}<0.001$ & -0.62 & 3.8 & 0.0 .21 & $\begin{array}{c}\text { Not } \\
\text { significant }\end{array}$ \\
\hline
\end{tabular}

Table 3 revealing a statistically significant difference between Qatari males and Jacobson's subjects $(\mathrm{P}<0.05)$. There was no significant difference when compared to the Robertson and Pearson result.

TABLE III: COMPARISON OF WITS APPRAISAL MEAN VALUES BETWEEN The Present Study ANd Those Of Jacobson $(9,16)$, ANd Robertson

\begin{tabular}{cccccc}
\multicolumn{5}{c}{ AND PEARSON (20) } \\
\hline & No & Mean & SD & $\begin{array}{c}\text { P- } \\
\text { Value }\end{array}$ & Comment \\
\hline $\begin{array}{c}\text { Qatari } \\
\text { Present study }\end{array}$ & 28 & 0.5 & 2.96 & & \\
$\begin{array}{c}\text { South Africa } \\
\text { Jacobson (9, 16) } \\
\text { South Wales, UK } \\
\text { Robertson and } \\
\text { Pearson (20) }\end{array}$ & 21 & -1.17 & 1.90 & 0.028 & Significant \\
\hline $\mathrm{P}<0.05 *, \mathrm{P}<0.01 * *, \mathrm{P}<0.001 * * *$ NS: Not Significant. & -0.10 & 1.90 & 0.390 & $\begin{array}{c}\text { Not } \\
\text { significant }\end{array}$ \\
\hline
\end{tabular}

Table 4 showing no significant difference when comparing Qatari males to Saudi males from the central and Western region of Saudi Arabia, or to Kuwaiti males.

TABLE 4: COMPARISON OF Wits APPRAISAl MEAN VALUES BETWEeN QATARI MALES, SAUDi ARABIANS FROM THE CENTRAL AND WESTERN REGION OF THE KINGDOM, AND KUWAITI NATIONALS

\begin{tabular}{|c|c|c|c|c|c|}
\hline & No & Mean & SD & $\begin{array}{c}\text { P- } \\
\text { Value }\end{array}$ & Comment \\
\hline $\begin{array}{c}\text { Qatari } \\
\text { Present study }\end{array}$ & 28 & 0.5 & 2.96 & & \\
\hline $\begin{array}{l}\text { Saudi (Western } \\
\text { region) } \\
\text { AL-Zawawi (24) }\end{array}$ & 25 & -0.73 & 2.48 & 0.109 & $\begin{array}{c}\text { Not } \\
\text { significant }\end{array}$ \\
\hline $\begin{array}{l}\text { Saudi (Central } \\
\text { region) } \\
\text { AL-Barakati (23) }\end{array}$ & 30 & 0.082 & 2.20 & 0.640 & $\begin{array}{c}\text { Not } \\
\text { significant }\end{array}$ \\
\hline $\begin{array}{c}\text { Kuwaiti } \\
\text { AL-Jame et al } \\
(26)\end{array}$ & 82 & 0.048 & 2.36 & 0.078 & $\begin{array}{c}\text { Not } \\
\text { significant }\end{array}$ \\
\hline
\end{tabular}

Table 5, A high level of statistically significant difference was found between Qatari males and South Chinese males, 
but no significant difference was found when compared to South Koreans and Japanese males.

TABLE 5: COMPARISON OF WITS APPRAISAL MEAN VALUES BETWEEN QATARI MALES, SOUTH KOREANS, SOUTH CHINESE, AND JAPANESE

\begin{tabular}{|c|c|c|c|c|c|}
\hline & No & Mean & SD & $\begin{array}{c}\mathrm{P}- \\
\text { Value }\end{array}$ & Comment \\
\hline $\begin{array}{c}\text { Qatari } \\
\text { Present study }\end{array}$ & 28 & 0.5 & 2.96 & & \\
\hline $\begin{array}{l}\text { South Korean } \\
\text { (27) Kim et al }\end{array}$ & 102 & -0.33 & 2.73 & 0.164 & $\begin{array}{c}\text { Not } \\
\text { significant }\end{array}$ \\
\hline $\begin{array}{l}\text { South Chinese } \\
\text { So et al (21) }\end{array}$ & 55 & -4.88 & 3.61 & 0.0001 & $\begin{array}{l}\text { Extremely } \\
\text { significant }\end{array}$ \\
\hline $\begin{array}{c}\text { Japanese } \\
\text { Miyajima et } \\
\text { al. (29) }\end{array}$ & 26 & -0.50 & 2.50 & 0.187 & $\begin{array}{c}\text { Not } \\
\text { significant }\end{array}$ \\
\hline
\end{tabular}

Table 6 depicting a high level of statistically significant difference between Qatari males and Nigerians, but none between Qatari males and black Americans.

TABLE 6: COMPARISON OF WITS APPRAISAL MEAN VALUES BETWEEN QATARI MALES, NIGERIANS, AND BLACK AMERICAN

\begin{tabular}{|c|c|c|c|c|c|}
\hline & No & Mean & SD & $\begin{array}{c}\mathrm{P}- \\
\text { Value }\end{array}$ & Comment \\
\hline $\begin{array}{c}\text { Qatari } \\
\text { Present study }\end{array}$ & 28 & 0.5 & 2.96 & & \\
\hline $\begin{array}{c}\text { Nigerians } \\
\text { Ucheonye et al } \\
\text { (22) }\end{array}$ & 34 & -4.16 & 3.65 & 0.0001 & $\begin{array}{l}\text { Extremely } \\
\text { significant }\end{array}$ \\
\hline $\begin{array}{c}\text { Black } \\
\text { American } \\
\text { Connor \& } \\
\text { Moshiri (28) } \\
\end{array}$ & 25 & 0.59 & 3.84 & 0.923 & $\begin{array}{c}\text { Not } \\
\text { significant }\end{array}$ \\
\hline
\end{tabular}

\section{DISCUSSION}

A cephalometric radiograph is often used in the diagnosis and treatment planning of patients seeking orthodontic treatment. Cephalometry finds wide application in describing the morphology and growth of the facial skeleton, predicting growth, establishing the diagnosis, and planning appropriate orthodontic therapy. The ANB angle is one of the variables measured on the cephalogram to indicate the skeletal relationship of the maxilla to the mandible. However, several researchers have questioned this practice; their concerns have centered around the instability of the Nasion point during growth in early life. A posteriorly positioned Nasion will increase the ANB angle; conversely, a more anteriorly positioned point will decrease the angle. Additionally, it is not uncommon for the original Nasion reference point to shift up or down slightly [25]. Jacobson introduced the Wits appraisal as a reliable alternative to the ANB angle in assessing the sagittal relationship between the maxilla and the mandible. He did this by drawing perpendicular lines from each of Point $\mathrm{A}$ and Point $\mathrm{B}$ to the occlusal plane and measuring the distance between these two lines. Point BO was found to be approximately $1 \mathrm{~mm}$ ahead of point $\mathrm{AO}$ with a range of -2 to $4 \mathrm{~mm}$, and a mean reading of $-1.17 \pm 1.90 \mathrm{~mm}$ [9]. The results of the present study on Qatari males were significantly different from those of Jacobson. This could be attributed to racial difference. This finding contrasts with that of $\mathrm{Al}$ Zawawi who found no significant difference between his population of Western Saudi Arabians and Jacobson's results.

Comparison between findings from the present study and the South Wales sample revealed no significant difference as was the case when compared to Al Barakati's population of Central Saudi Arabian dental students. However, the results of the present study and that of Al-Barakati revealed no sexual dimorphism. This was not the case for AL-Zawawi's study which reported a difference of high statistical significance between females and males and concluded that the Wits appraisal appears to be more gender-specific and less ethnicity- specific. [24]. The mean value of the wits appraisal in the Qatari males studied was significantly greater than that reported in Jacobson's study [9], [16], in Chinese [21], or in Nigerians [22]. This may be attributed in part to the prevalence of a protrusive maxilla amongst Qatari males, a factor which contributes to midfacial prominence and a tendency towards Class II malocclusion when compared to the other races, such as the Chinese, who tend more towards a Class III malocclusion.

Comparing the findings from the present study with those from Black African studies revealed an absence of consistency: A Nigerian population revealed a difference with a high level of statistical significance. On the other hand, similar comparison with a population of black Americans [27] did not reveal a statistically significant difference. Similar inconsistency was evident when comparing the Qatari male population to Mongoloid samples: Differences with high statistical significance were noted when comparison was made with South Chinese males [28], yet none was found when South Korean [29] and Japanese males [30] were compared to Qataris, despite all of these groups being from the same race. In contrast to the statement from the Zawawi study [24] previously quoted, this substantiates the theory that the Wits appraisal is not ethnicity- specific as well as being non gender-specific. Several investigators have highlighted the valuable contribution that cone beam computed tomography (CBCT) can make by yielding a threedimensional view [29]. The information gained from the application of this technology can provide the orthodontist with valuable information applicable to the diagnosis and treatment planning of the case. The findings of previously published studies [9], [31], [32] would seem to indicate that the Wits appraisal is a more reliable indicator of sagittal dental base discrepancy than the ANB angle is. Considering this, it is suggested that the Wits appraisal be used as an alternative to, or in conjunction with the ANB angle in the treatment of borderline cases [22].

\section{CONCLUSION}

The Wits appraisal value for the Qatari male population studied was $0.5 \pm 2.96$, a result which is significantly higher than that reported in Jacobson's study. This study revealed that the Wits appraisal is not ethnicity or gender-specific, and therefore cannot be used to differentiate between different ethnic groups. However, it can find application as an alternative to the ANB angle in the treatment of borderline cases. The application of cone beam computed tomography (CBCT) will enhance the diagnosis and treatment of cases by yielding three-dimensional views. 


\section{ACKNOWLEDGMENT}

We would like to thank Hamad Medical Corporation/ Hamad Medical Research Center for sponsoring this research (Sub-Research Proposal Number 15041/150). The authors heartily acknowledge Dr. Keith AL-pine for the invaluable help and support in editing the manuscript. Thanks, extended to Dr. Hashim AL-Hussain for his help in statistical analysis and to Professor Anil Sukumaran for preparing the final template.

\section{REFERENCES}

[1] Broadbent BA new X-ray technique and its application to orthodontia. Angle Orthod.;51:93-114.1931.

[2] Hofrath H. Bedeutung der röntgenfern und abstands aufnahme fürdie diagnostik der kieferanomalien. Fortschritte der Orthodontie.;1:231 58. 1931.

[3] Downs WB. Variations In Facial Relationship: Their Significance In Treatment and Prognosis1. Angle Orthod.; 19:145-55. 1949.

[4] Steiner CC. Cephalometrics for you and me. Am J Orthod.;39:729-55. 1953.

[5] Tweed CH. The Frankfort-Mandibular Incisor Angle (FMIA) In Orthodontic Diagnosis, Treatment Planning and Prognosis. Angle Orthod:;24:121-69.1954.

[6] Mills JR. Principles and Practice of Orthodontics. Churchill Livingstone, Edinburgh.1982.

[7] Sassouni V. A roentgenographic cephalometric analysis of cephalofacio-dental relationships. Am J Orthod. 41:735-64.1955.

[8] Ricketts, R. M. Cephalometric Analysis and Synthesis. Angle Orthod.;67:141-56. 1961.

[9] Jacobson, A. The Wits appraisal of jaw disharmony. Am J Orthod.;67:125-38. 1975.

[10] McNamara, J. A., Jr. A method of cephalometric evaluation." Am J Orthod.;86:449-69.1984.

[11] Riedel RA. The relation of maxillary structures to cranium in malocclusion and in normal occlusion. Angle Orthod.;22:142-45. 1952.

[12] Steiner CC. Cephalometrics in clinical practice. Angle Orthod.;29:829. 1959.

[13] Ricketts RM. The influence of orthodontic treatment on facial growth and development. Angle Orthod.;30:103-33.1960.

[14] Chang HP. Assessment of anteroposterior jaw relationship. Am J Orthod Dentofacial Orthop.;92:117-22, 1987

[15] Bishara SE, Fahl JA, Peterson LC. Longitudinal changes in the ANB angle and Wits appraisal: Clinical implications. Am J Orthod.;84:13339. 1983.

[16] Jacobson A. Application of the "Wits" appraisal. Am J Orthod.;70:179-89. 1976.

[17] Jarvinen S. Relation of the Wits appraisal to the ANB angle: A statistical appraisal. Am J Orthod Dentofacial Orthop.;94:432-35. 1988.

[18] Nanda RS. Growth changes in skeletal-facial profile and their significance in orthodontic diagnosis. Am J Orthod.;59:501-13. 1971.

[19] Jenkins DH. Analysis of orthodontic deformity employing lateral cephalometric radiography. Am J Orthod.;41:442-52. 1955.

[20] Robertson NR, Pearson CJ. The wits appraisal of a sample of the South Wales population. Br J Orthod.;7:183-84.1980.

[21] So LY, Davis J, King NM. Wits appraisal in Southern Chinese children. The Angle Orthodontist.;60:43-47. 1990.

[22] Ifesanya Joy Ucheonye, Adeyemi Abigail Tokunbo, Otuyemi Olayinka Donald. The Wits appraisal among a Nigerian sub-population: an assessment of dental base geometric factors. Braz J Oral Sc.; 12:27579. 2013.

[23] Al-Barakati SF. The wits appraisal in a Saudi population sample. Saudi Dent J.; 14:89-92.2002.

[24] Khalid H. Zawawi. Comparison of Wits appraisal among different ethnic groups. J Orthod Sci.; 1:88-91. 2012.

[25] Ib Leth Nielsen. (Cephalometric Analysis of Growth and Treatment with the Structural Technique: A Review of its Background and Clinical Application Taiwanese Journal of Orthodontics., Vol. 30. No. 2. $68-81,2018$

[26] Al-Jame B, Artun J, Al-Azemi R, Behbehani F, Buhamra S. Lateral cephalometric norms for adolescent Kuwaitis: Hard tissue measurements. Med Princ Pract.;15:91-97. 2006.
[27] Kim YH, Vietas JJ. Anteroposterior dysplasia indicator: An adjunct to cephalometric differential diagnosis. Am J Orthod; 73:619-33. 1978

[28] Connor AM, Moshiri F. Orthognathic surgery norms for American Black patients. Am J Orthod.;87:119-34.1985.

[29] Miyajima K, McNamara JA Jr, Kimura T, Murata S, Iizuka T. Craniofacial structure of Japanese and European-American adults with normal occlusions and well-balanced faces. Am J Orthod Dentofac Orthop; 110:431-8. 1996

[30] Hayder Abdalla Hashim, Najah AL-Sayed, Feras Abed AL Jawad, Ayah AL-Qaisi. Wits Appraisal Among Qatari Females: A Comparative Study. European Journal of Medical and Health Sciences. July 2020; Vol. 2, No. 4,365-68.

[31] Rongo, R., D'Antò, V., Bucci, R. Polito, I. Martina, R., \& Michelotti, A.). Skeletal and dental effects of Class III orthopaedic treatment: A systematic review and meta-analysis. J Oral Rehab.;44,545-62. 2017.

[32] Woon, S. C., \& Thiruvenkatachari, B. Early orthodontic treatment for Class III malocclusion: A systematic review and meta-analysis. Am. J. of Orthod. and Dentofac. Orthoped.;151:28-52. 2017.

[33] Zhou L, Mok C-W, Hägg U, McGrath C, Bendeus M, Wu J. Anteroposterior dental arch and jaw-base relationships in a population sample. Angle Orthod.;78:1023-29. 2008.

[34] Shendre S, Karan GK, Ravinarayana RPR, Mamtha T. Correlation of the anteroposterior relationships of the dental arch and jaw-base in subjects with class I, class II and class III malocclusions. Int J Contemporary Dent; 2:68-73. 2011. 